\title{
ЭСТЕТИКА
}

\author{
Н.Б. Маньковская
}

\section{МИСТИКО-СИМВОЛИЧЕСКАЯ МЕТАФИЗИКА ИСКУССТВА ЖОЗЕФЕНА ПЕЛАДАНА}

Аннотация. Предметом исследования является метафизика искусства Жозефена Пеладана как видного представителя мистической ветви французского объективного символизма, его неоплатонико-христианской линии. Особое внимание уделяется его полемике со Львом Толстым, его анализу творчества Данте, античной и современной драматургии и театра. Рассматривается пеладановская концепции соотношения искусства и религии, художественного творчества, эстетического созерцания и наслаждения, прекрасного, возвышенного, трагического, комического, эстетического идеала, эстетического наслаждения, художественности, сущности художественного образа, символизации в искусстве, его анагогической миссии. Многоаспектность настоящего исследования предопределила применение ряда методологических подходов: искусствоведческий анализ, философско-эстетический подход, компаративистский, междисциплинарный методы. Основным выводом проведенного исследования является заключение о том, что три ипостаси Пеладана - символиста, неоклассика и эзотерика - образуют парадоксальное, но достаточно органическое единство. Его размышления о сущности эстетического, специфике разных видов и жанров искусства объединены пафосом отстаивания вечно прекрасного, абсолютного идеала, нетленных идей, духовной наполненности, художественности искусства. Особым вкладом автора в исследование темы заключается в том, что оно выполнено на полностью оригинальном материале. Автор вводит в отечественный научный оборот ранее не исследовавшиеся аспекты французского символизма. Метафизика искусства Ж. Пеладана в отечественной науке исследуется впервые.

Ключевые слова: символизм, мистицизм, искусство, литература, театр, художник, прекрасное, идеал, художественность, символизация.

Abstract. The subject of the research is the arts metaphysics of Josephin Peladan as a remarkable representative of the mysticism branch of the French objective symbolism, in particular, its Neo-Platonist Christian movement. Special attention is paid to his polemics with Lev Tolstoy, his analysis of Dante's creative work, ancient and modern dramaturgy and theatre. In her research Mankovskaya also analyzes Peladan's ideas about the relationship between art and religion, artistic creativity, aesthetic contemplation and pleasure, ideals of beauty, tragic, comic, aesthetic ideals, artisticity, essence of an artistic image, symbolization in art and anagogic mission of art. Such a great variety of aspects covered by the present research created the need to apply a number of methodological approaches such as art analysis, philosophical aesthetic approach, comparative and interdisciplinary methods. The main conclusions of the research is that Peladan's three hypostases as a symbolist, neoclassicist and esoteric create a paradoxical but organic unity. His thoughts on the nature of esoterics, particular artistic types and genres have one thing in common which is the idea of beauty, absolute ideal, undying values, spiritual and artistic components of art. Special contribution made by the author to the analysis of the topic is that she uses only original materials in her research. Mankovskaya introduces aspects and works of French symbolism that have never been studied before. Josephin Peladan's arts metaphysics is studied for the first time in the Russian academic literature, too.

Key words: articity, ideal, beauty, artist, theatre, literature, art, mysticism, symbolism, symbolyzation.

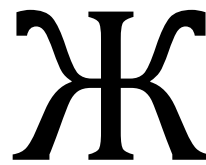
озефен (Сар) Пеладан (1858 - 1918) видный представитель мистической ветви французского объективного символизма, его христианско-неоплатонической линии, чьи труды отмечены пафосом борьбы против упадка эстетики и латинского мира в целом, противоядием против которого ему представляются идеализм, символизм и мистицизм. Он выступал убежденным защитником высокой культуры, художественности, красоты, эстетического наслаждения, анагогической миссии искусства [4]. Как основатель ордена христианских розенкрейцеров - «Розенкрейцерского Католического и Эстетического Ордена Храма и Грааля» - Пеладан задавался целью восстановления утраченных, как он полагал, знаний и идеалов католицизма, основой 
для которого станет традиция, платформой - искусство, а средством - красота: подлинное искусство обладает божественной, анагогической миссией, возвышающей душу. Пеладан полагал себя основателем новой религии, соединяющей воедино розенкрейцерство и католицизм посредством искусства. Однако по существу его движение оказалось литературно-эстетическим, что выразилось как в инициируемых им художественных выставках и вечерах, посвященных искусству - Салонах «Роза + Крест» (1892-1897), так и, главное, в создании огромного корпуса трудов философско-эстетического и мистического плана, а также романов и пьес. Он автор около девяноста книг и множества статей. Наиболее фундаментальные среди его многотомных «этопей» - «Упадок латинского мира» (21 том), «Упадок эстетики» (17 томов), «Амфитеатр мертвых наук» (7 томов).

Резко критикуя, как и другие французские символисты, Ипполита Тэна и Эмиля Золя как провозвестников позитивизма в философии и натурализма в искусстве, Пеладан видел в символизме и мистицизме путь к избавлению от уродства современного мира посредством ресакрализации искусства и жизни. В центре его эстетических интересов - сущность эстетики и искусства, миссия художника, природа гениальности, категории прекрасного, возвышенного, трагического, героического и их антипода - безобразного, проблемы канона в искусстве, художественного вкуса и его воспитания, эстетического наслаждения. Эстетику он мыслил как «теорию форм, возводящих к идеалу» [10, с. 46,]. Пеладан дает свое определение эстетики, дистанцируясь от ее традиционного понимания как науки о прекрасном, философии изящных искусств: «Эстетика - искусство чувствовать Бога в вещах: того, кто это чувствует, я называю Художником, Артистом, то есть превосходным, лучшим. Таким образом, предмет возвышается, эстетика становится теологией сердца и вибрации. Я возвращаю возвышенность этой профанированной, светской науке» [8, с. 9-10]; подлинная задача искусства - возвышать душу. Искусство - зеркало, отражающее божественное, способ сделать невидимое видимым, оно исполнено мистических тайн; искусство, служащее идее и идеалу (а таковым для Пеладана и является искусство символизма) «призвано заменить религию, жажду сакрального, идеала, мистицизма, лиризма» [11, с. 91]. Прекрасное же в искусстве - это идея, находящая в нем чувственное выражение [8, с. 52-53, 7]. Главная функция искусства, по Пеладану, - эстетическая, все иные функции - познавательная, коммуникативная, социальная и т.п. не являются для него сущностными. Развитый эстетический вкус побуждает реципиента к эстетическому созерцанию, завершающемуся эстетическим наслаждением. В вечном эстетическом споре о «древних» и «новых» Пеладан решительно выступает в защиту древних и классиков, чьим художественным ориентиром была не «физика», но «метафизика» искусства.

Эстетические взгляды Ж. Пеладана нашли концептуальное развитие применительно к различным видам искусства - живописи, литературе, театру. Наиболее репрезентативными для его видения искусства как эстетического феномена являются его полемика с Л.Н. Толстым, анализ творчества Данте и спор с Леонардо да Винчи $[2,6]$.

\section{Полемика со Львом Толстым}

«Упадок эстетики. Ответ Толстому»- резко критическая реакция на знаменитую статью «Что такое искусство?». Это одно из программных, доктринальных сочинений Пеладана, имеющих для него как эстетика принципиальный характер [10]. В трактате Л.Н. Толстого «Что такое искусство?» Пеладан видит путь эстетического упадка. Резкость критики «эстетики отрицания эстетического» [1] Толстого в поздний период его творчества во многом связана у Пеладана с более масштабной проблемой упадка, заката латинского мира в целом, крушение которого может ускорить «русский колосс», хотя мужик и поделится хлебом с побежденным латинским мальчиком-с-пальчиком [10, с. 7]. Французский мыслитель видит в русских молодой, мистический, верующий народ, признавая, что будущее - за ним. Однако как человек, никогда серьезно не изучавший русскую культуру, он представляет себе Россию стремящейся к мировому господству, обладающей силой, но не интеллектом «страной мужиков», относя к таковым и Толстого - «великого мужика», христианина и «славянского людоеда» одновременно, стремящегося опустить искусство до уровня понимания «Пьяных мужиков» $[10$, с. 10]. Отмечая, что Толстой отрицает собственное литературное творчество во имя своих новых эстетических идей, направленных на утверждение «эстетически неразвитой, далекой от метафизики крестьянской литературы» [10, с. 13], Пеладан полагает, что русский писатель посягает тем самым на основы западной цивилизации: беря на себя роль «христианского инквизитора», Толстой, усугубляя негативизм Платона и Руссо в отношении искусства, сваливает на него все зло, выносит искусству «вздорный приговор», перечеркивая тем самым творчество Эсхила, Софокла, Микеланджело, Гёте, Баха, Малларме, Вагнера и предлагая взамен доступные для массового понимания жанровые зарисовки (к ним Пеладан относит романы Дюма-отца, «Отверженных В. Гюго, «Хижину дяди Тома» Г. Бичер-Стоу, произведения Ч. Диккенса). 
«Упадок эстетики. Ответ Толстому» возможно, и конкретный ответ Пеладана на критику русского писателя в его собственный адрес, заметившего по поводу пеладановского труда «Искусство идеалистическое и мистическое», что «книга эта очень фантастическая и очень невежественная...» [5, c. 73]. Не менее резко отзывался Толстой и о других западноевропейских символистах как продолжателях и подражателях тех художественных традиций Античности и Ренессанса, которые Пеладан ценил очень высоко: «Только благодаря критикам, восхваляющим в наше время грубые, дикие и часто бессмысленные для нас произведения древних греков: Софокла, Эврипида, Эсхила, в особенности Аристофана, или новых: Данте, Тасса, Мильтона, Шекспира; в живописи - всего Рафаэля, всего Микеланджело с его нелепым «Страшным судом»; в музыке - всего Баха и всего Бетховена с его последним периодом, стали возможны в наше время Ибсены, Метерлинки, Верлены, Малларме, Пювис де Шаваны, Клингеры, Бёклины, Штуки, Шнейдеры, в музыке - Вагнеры, Листы, Берлиозы, Брамсы, Рихарды Штраусы и т. п., и вся та огромная масса ни на что не нужных подражателей этих подражателей» [5, с. 154].

Ответ Пеладана Толстому строится на его принципиальном несогласии с главными положениями трактата «Что такое искусство?», прежде всего, с пафосом опрощенчества, с отторжением его автором профессионального «господского» искусства как вычурного и неясного, утратившего свои религиозные основания, в пользу искусства народного, исполненного глубинным религиозным чувством. Неприемлем для Пеладана толстовский негативизм в отношении прекрасного, художественности, эстетического качества искусства в целом, тенденции растворения искусства в жизни. Французский эстетик в корне не согласен с разведением Толстым красоты, добра и истины вплоть до их противопоставления, ригористическим неприятием эстетического наслаждения как пагубного в нравственном отношении. Отвергает он и толстовскую идею о коммуникативности искусства как его основной функции. Полемика с русским писателем служит Пеладану еще одним поводом для изложения собственных представлений о сущности эстетики и искусства.

В корне отвергая суждения позднего Толстого об искусстве в целом, поглощающем «огромные труды народа и жизней человеческих и нарушающее любовь между ними» $[5$, с. 50], и его религиозноэтический ригоризм, «утилитаризм в религиозной упаковке» [10, с. 15], в частности, Пеладан замечает, что между искусством и действительностью такая же пропасть, как между гневом Эдипа и яростью мужика, избивающего жену. Не видя этой пропасти,
Толстой ориентируется на «низкопробный реализм Золя, самого некультурного из современных писателей» $[10$, с. 27], принижая тем самым простой народ, который способен ценить подлинное искусство - ведь эстетический вкус народа, подчеркивает Пеладан, выше, чем у буржуазии, приверженной бульварному театру: «Неправда, что народу нужно народное искусство. Народ стремится к возвышенному» $[10$, с. 271$]$.

Предвосхищая некоторые идеи Анри Бергсона, высказанные им в эстетическом трактате «Смех» (1900), Пеладан говорит о том, что «истинно культурный человек признает только трагедию (...) смех развращает, вульгарностьзаразна, асовременностьшкола дурных нравов» [10, с. 29] (в другом месте он пишет о том, что «смеху нет места в подлинном искусстве», возможны только улыбка, редко - плач [6, с. 165]); в трагедии зашифровано тайное знание, тогда как содержание комедии сводится лишь к резонерству, практической морали, повседневности: в отличие от «Тристана и Изольды», парижские комедии - всего лишь пособие по адюльтеру. И делает безапелляционный энергичный вывод: «Искусство, стремящееся удовлетворить публику - всего лишь низкая проституция» [10, с. 31]. Он настаивает на том, что в искусстве, как и в жизни общества, необходима иерархия, а не равенство.

В данном контексте главная претензия Пеладана к Толстому-эстетику состоит в том, что тот принижает искусство и прекрасное в пользу обыденности. Однако «художник, говорящий только о жизни, скажет очень мало (...) искусство начинается там, где кончается жизнь» [10, с. 35] (ирреальность «Джоконды» как художественного шедевра Пеладан противопоставляет «живым» персонажам не слишком ценимого им Рембрандта). Правила в искусстве задают шедевры, а не житейский опыт, заключает он. Внося свою лепту в «вечный» эстетический спор о том, что выше - искусство или природа, он решительно выступает в пользу приоритета искусства, солидаризируясь с классицистской линией на следование художественным образцам.

Главный изъян концепции Толстого Пелдан справедливо усматривает в разрушении им классической «тройной гармонии прекрасного как чувственно-истинного, истины как концептуализированного, осознанного прекрасного и блага реализации прекрасного и истинного» [10, с. 60]. Его серьезный упрек в адрес Толстого заключается в том, что в своем трактате он, вопреки античным идеям калокагатии, разводит красоту, добро и истину, противопоставляет их («Понятие красоты не только не совпадаем с добром, но скорее противоположно ему (...) Чем больше мы отдаемся красоте, тем больше мы удаляемся от добра» [5, с. 101]), 
считая современное искусство «пустой забавой праздных людей» [5, с. 102], получающих от него наслаждение и возбуждающих с его помощью свою чувственность, «так что вследствие безверия и исключительности жизни богатых классов искусство этих классов обеднело содержанием и свелось все к передаче чувств тщеславия, тоски жизни и, главное, половой похоти» [5, с. 113]. Искусство же, убежден Пеладан, непосредственно приближает душу к высшему миру, возводит к свету абсолюта: «Удовольствие от произведения искусства расширяет нравственную жизнь, сразу возвышает индивида» [10, с. 41]. Искусство призвано усовершенствовать человека; оно - преддверие не ада, а рая. И путь такого усовершенствования - художественность как сущность искусства, а не воспитательная или какая-либо иная, побочная для него функция: «Искусство - не педагогика, а лучезарный завет, пробуждающий жизнь души посредством образов и лирики» [10, с. 41].

ЕщеодинобъектполемикиПеладанасТолстымпроблема прекрасного. Достаточно мимолетного взгляда, чтобы восхититься фреской, монументом, статуей, убежден Пеладан: «Воспроизведение высшего мира возможно лишь благодаря проявлениям Красоты» [10, с. 42]. А по Толстому, идея красоты запутывает вопрос о том, что такое искусство: «...красота, или то, что нам нравится, не может служить основанием определения искусства, и ряд предметов, доставляющих нам удовольствие, никак не может быть образцом того, чем должно быть искусство. (...) Люди поймут смысл искусства только тогда, когда они перестанут считать целью этой деятельности красоту, то есть наслаждение» [5, с. 81]. Но возможны ли право без правосудия, наука без истины, мораль без блага, то есть без своего объекта? - риторически вопрошает Пеладан. И дает твердый ответ: разумеется нет; предмет искусства - прекрасное.

Отрицает он и идею Толстого о том, что искусство повторяет чувства художника («Деятельность искусства основана на том, что человек, воспринимая слухом или зрением выражения чувства другого человека, способен испытывать то же самое чувство, которое испытал человек, выражающий свое чувство» [5, с. 85]). Согласно Пеладану, «искусство не является воскрешением чувств, пережитых художником» $[10$, с. 44] - так мыслят только индивидуалисты: Данте не спускался в Ад, Софокл не женился на своей матери, а «Гюстав Моро, чье творчество - череда героических аллегорий и символов, прожил совершенно спокойную жизнь» [10, с. 45].

Решительно не согласен он с Толстым и в том, что, по мнению последнего, для точного определения искусства нужно рассматривать его не как средство наслаждения, а как одно из условий человеческой жизни, а именно как средство коммуникации: «Искусство есть деятельность человеческая, состоящая в том, что один человек сознательно известными внешними знаками передает другим испытываемые им чувства, а другие люди заражаются этими чувствами и переживают их» $[5$, с. 87]; искусство есть одно из средств общения людей между собой. Религия - тоже, но в каком смысле? - вопрошает Пеладан. И дает свой ответ: «на основе идентичности чувств. Искусство, как и религия, средство общения людей с идеалом, с потусторонним, а не с другими людьми» [10, с. 46]. Искусство не должно быть зеркалом чужих страданий. Пеладан убежден в том, что оно - украшение человеческой жизни.

Развивая эту мысль, Пеладан эстетик высказывает принципиальное несогласие с идеями Толстого о подчинении искусства нравственно-религиозным целям. Пеладан возвращается в этом контексте к одной из своих магистральных идей о том, что «искусство - часть религии, пережившая ее догматы» [10, с. 50]: «искусство - последняя искорка Святого Духа, светящая нам на закате, когда угас мистический очаг: а этот казак хочет загасить ее» $[10$, c. 65]. При он этом подчеркивает значимость художественно-эстетической стороны религиозного обряда: важна не столько католическая проповедь, сколько исполняемые на органе шедевры Баха и Палестрины. Ведь, по его убеждению, все лучшие человеческие чувства обязаны своим существованием эстетическому вкусу, любви к искусству.

Продолжая эту линию, Пеладан говорит о том, что людей разделяют ныне не этнические и религиозные признаки, а степень цивилизованности. Во многом идеализируя реальное положение вещей, французский символист полагает, что представители разных конфессий любят искусство, понимают друг друга на основании того, что «эстетические чувства образуют самые крепкие связи между людьми» $[10$, с. 51]. Ссылаясь на эстетику и искусство католического ренессанса XIX в. (Ф. де Шатобриан, А. де Ламартин, Ф. Вилье де Лиль-Адан, Ш. Бодлер) и проникнутые глубокой религиозностью шедевры Рафаэля, Леонардо, Микеланджело, Пеладан категорически не соглашается с Толстым в его оценке искусства Ренессанса как отхода от религии.

В пылу полемики Пеладан, проводя аналогии между ригоризмом Толстого и мусульманским фанатизмом, направленным, например, на запрет изображения человеческой фигуры, называет русского классика «Омаром Толстым» (показательно, что и современный отечественный ученый пишет в этой связи о «почти исламской ригористической позиции» Толстого [1, с. 341$])$, фанатиком, готовым во- 
обще отказаться от искусства на том основании, что лучше жить без искусства, чем с «плохим» искусством. Хорошим же для него, в интерпретации Пеладана, является то, что доставляет удовольствие невеждам, безграмотным: Толстой «готов сжечь библиотеку человечества, потому что русский пьяница ничего в ней не смыслит» $[10$, с. 46].

В споре с Толстым Пеладан, по существу, излагает свою позицию в отношении имплицитной и эксплицитной эстетики. Комментируя высказывание Толстого о том, что эстетика выдумана людьми XVIII века и в 1750 г. «специально обделана в теорию Баумгартеном» [5, с. 99], Пеладан иронически замечает, что оно равносильно попытке приписать явление магнетизма выявившему его Месмеру. Эстетика не сводится к эстетическим трактатам, эстетические идеи художников содержатся в их произведениях: «Теория искусство возникает, когда произведение уже создано» [10, с. 59].

Пеладан убежден в том, что искусство призвано пробуждать высокие чувства, возводить от земной любви к небесной: у любви есть крылья, она воспаряет, возносится, взлетает в выси, недоступные для тяжеловесных рассуждений. И утверждает свое кредо: «Суть искусства, как и религии, состоит в его таинственности: дабы получить его дар, нужно восхищаться и молиться (...). Искусство должно помочь нам расправить крылья» [10, с. 271].

В этом ключе Пеладан решительно выступает против профанации искусства, его омассовления, растворения в жизни. Ни в коей мере не разделяя толстовские идеи опрощенчества, он подчеркивает, что моральное и интеллектуальное развитие личности зависит от свободного времени, досуга, язвительно отмечая при этом, что писатель вовсе не должен производить бумагу - ведь в основе современной цивилизации лежит разделение труда (попутно Пеладан со свойственным ему снобизмом замечает, что людям его круга негоже самим пришивать пуговицы и стирать носовые платки). Неприемлемы для него и восходящие к руссоизму идеи русского писателя о том, что изящные искусства родились благодаря порабощению народных масс («...наше утонченное искусство могло возникнуть только на рабстве народных масс и может продолжаться только до тех пор, пока будет это рабство...» [5, с. 105]). Решительно выступая против искусства для масс (под “эстетическим кнутом" Толстого все равны, а подлинное искусство для него - мужицкое» $[10$, с. 71$])$, Пеладан сурово критикует русского писателя за то, что он предлагает не массы поднимать до искусства, а опустить искусство до их уровня. Сводить искусство к описанию «толпы мужиков» значит принижать его; следует помнить, что Орест - не мужик: «Единственный персонаж искус- ства - герой, ярко воплощающий патетические проблемы человечества» [10, с. 74]. Неприемлема для него и толстовская мысль о том, что профессионализм и обучение искусству в художественных школах, которые «распложают в огромном количестве то поддельное искусство, извращающее вкус масс, которым переполнен наш мир [5, с. 158]», губительны для искусства («невозможно выучить человека тому, чтобы он стал художником» [5, с. 158]), и в будущем художником сможет стать любой, все будут художниками (сегодня, более ста лет спустя, пеладановская критика звучит как нельзя более злободневно в свете дилетантизма многих представителей арт-практик, стремящихся выдать неискусство за искусство, стереть грани между ними). Пеладан решительно выступает против примитивизации искусства, его превращения в форму массового досуга наподобие спорта, охоты, рыболовства. А также против ханжества позднего Толстого, не приемлющего изображения в искусстве любовных сцен.

Общий вывод Пеладана относительно содержания трактата «Что такое искусство?» весьма категоричен, но справедлив: «Толстой глух к искусству» $[10$, с. 75]. Он уличает Толстого в «литературном нигилизме», называет его «Мартином Лютером от эстетики» [10, с. 87], подменившим художественность религиозностью. Отказ же от художественности и есть «путь эстетического упадка» [10, с. 89] - с этим заключением Пеладана, как и с его призывом проповедовать любовь к высокому искусству как «моральному органу человеческой жизни» $[10$, с. 96], можно солидаризироваться и сегодня.

\section{Анализ творчества Данте. Драматургия и театр}

Литературу Пеладан почитал высшим из искусств. В его собственных многочисленных и многообразных литературных произведениях имплицитно содержится немало художественно-эстетических идей. Свое эксплицитное выражение они нашли в трудах, носящих собственно литературоведческий характер («Тайна Трубадуров. От Парсифаля к Дон Кихоту», «Ключ к Рабле. Корпоративный секрет»). Наиболее репрезентативный среди них - «Учение Данте», книга, посвященная мистико-символической интерпретации «Божественной комедии».

Приступая к разбору поэтического шедевра Данте, Пеладан прежде всего отмечает, что каждая сцена у этого величайшего из пиитов, Гомера христианской эры - метафизическая формула, настоящий ребус. «Божественная комедия» подобна величественному собору. Однако «в нашу эпоху, которая безразлична к религии, неадекватна в философии и неспособна на страсть» [12, с. 39], восхищаются его размерами и пропорциями, не замечая символизма 
витражей, фигур на капителях - его эзотерического, мистического смысла. Пеладан предлагает интерпретацию аллегорий и символов в тексте Данте, прочитанном в качестве эзотерической, а не любовной лирики, мистического откровения.

Пеладан убежден в том, что Данте - католик лишь внешне, на самом же деле он гностик, член ложи Иоаннитов (рыцарей Мальтийского ордена). Язык его поэмы - это язык тайного общества, язык посвященных, свидетельство не столько поэтического искусства, сколько тайный шифр, своего рода учебник криптографии, квинтэссенция масонского учения: «Этот язык продирается сквозь колючий кустарник кавычек, он сеет и прививает» [12, с. 61]. Французский мистик интерпретирует «Божественную комедию» сквозь призму перипетий борьбы гвельфов и гибеллинов, проходившей на фоне противоборства между папством и империей за господство на Апеннинах - Данте был ее современником и участником. Пеладан считает Данте гибеллином, приверженцем власти императора, а не Папы римского (по его мнению, римская церковь для великого флорентийца - «гадкая, дегенеративная дочь благородных апостолов» [12, с. 106]), что импонирует воззрениям самого Пеладана - принципиального критика официальной католической церкви.

Обращаясь к символике «Божественной комедии», Пеладан различает в ней четыре смысловых уровня: экзотерический, эзотерический, аналогический, косвенный (воображаемый). Он прочитывает ее как апофеоз духовной, а не чувственной любви. Беатриче в его понимании - символ христианской религии, полностью проникнутой лютеранством анти-папской направленности; сам же Данте еретик. Но Беатриче - это и аллегория Богоматери, мудрости, философии. Она же в мистико-кабаллистическом духе - воплощение числа 9. Третье небо в дантовской религии любви - небо посвященных, масонов третьей степени.

При анализе книги Пеладана о Данте вызывает некоторое удивление, что, будучи достаточно тонким ценителем эстетического качества искусства, высказывая весьма точные и актуальные суждения о смысле и значении эстетики вообще, например, в полемике с Л.Н. Толстым, поднимая в иерархии искусств литературу и поэзию на высшую ступень, он в своей книге о великом европейском поэте практически не уделяет внимания анализу его художественного языка, средств художественного выражения тех идей, которые он изыскивает в этом произведении.

Особое значение придает Пеладан эстетическому трактату Данте «0 народной речи», направленному против средневековой латыни как языка искусственного, в защиту народного - итальянско- го - языка, подобного ячменному хлебу, способному насытить тысячи людей; таков природный дар, ему учатся, подражая кормилице. По мнению Пеладана, более точным для этого трактата было бы название «О свободомыслии народной речи» - Данте не дал его из страха перед инквизицией, ведь латынь - церковный язык, язык Папы римского. В обсуждаемом трактате французский мистик также усматривает тайный шифр. Так, в его интерпретации трагическое у Данте символизирует полезное (спасение), приятное (любовь) и честное (добродетель). Он видит в Данте поэта-теолога, для которого поэтическая народная речь как раз и является тайной доктриной. Язык самого Данте для него непереводим - теряется его эзотерический, оккультный смысл. Его творчество загадочно, непроницаемо, не поддается расшифровке: ведь Данте - не автор оригинальной системы, а мистик, приглашающий нас на символический пир. Доминанты его творчества - созерцание и анагогия: «его учение, как молния красоты, пронзает эпохи, несет на себе печать Святого Духа» [12, с. 110].

Современное воплощение тайной доктрины Данте, преодолевшей время и пространство, Пеладан находит в творчестве Вагнера. В «Парсифале» он усматривают линию, направленную против папства, власти денег: «Вагнер оживил идеал Данте (...) Ереси воплощаются в несравненных шедеврах» [12, с. 109]. Теологическим идеалом совершенства у Данте и Вагнера он считает неохристианство - и в этом плане полностью солидаризируется с ними.

Что же касается драматургии и театра, то, как и в искусстве в целом, Пеладана влечет их метафизическая сущность, сакральное происхождение, сокрытое в них тайное эзотерическое знание. Пеладан-драматург и теоретик театра задается целью восстановить изначальное призвание театрального искусства - создание ритуальной драмы, возрождающей традиции Элевсинских мистерий Древней Греции. И прилагает к этому немало усилий: в своей сочетающей античную и католическую символику «Прометеиде» (1895) он попытался «реконструировать в эзотерическом духе» $[9$, с. 151] трилогию Эсхила, исходя из убежденности в том, что «Прометей прикованный»-лишь ее центральная часть, которой предшествовал «Прометей-огненосец», а замыкал ее «Прометей освобожденный». Он сравнивал свою реконструкцию с гипотетической реставрацией Сикстинской капеллы, от которой не осталось бы ничего, кроме центральной фрески «Страшного суда».

А.Ф. Лосев в своей работе «Проблема символа и реалистическое искусство» отмечал: «Среди исканий в буржуазной литературе конца XIX в. Прометей 
Пеладана заслуживает особого упоминания. Прометей у Пеладана - прежде всего апостол, мученик и пророк истинного бога. [...] В наказании Прометея у Пеладана опять-таки можно усмотреть проявление воли высшего божества. Прометей прикован к скале не оттого, что похитил огонь (это лишь формальная причина), а, скорее, потому, что он должен страдать за все человечество. И Прометей выступает здесь не в роли богоборца, а в роли святого, великомученика, “страдальца за справедливость”. Прометей благодарит высшего бога и, стоя на коленях, рукою крестит себя. Однако замысел автора - создать образ Прометея святого в трилогии воплощается до некоторой степени противоречиво, поскольку вся вторая часть трилогии в значительной мере представляет перевод богоборческой трагедии Эсхила “Прометей прикованный”, который логически не вполне совмещается с идейно-художественной структурой пьесы» [3, с. 270-271].

Пеладан мечтал поставить свою «Прометеиду» в «Комеди Франсез», но получил отказ - не помогло ни его прошение на имя президента Французской республики, ни письмо министру просвещения и изящных искусств. Одним из его неосуществившихся замыслов было также основание театральной школы и хорового общества, направленных на возрождение древнего искусства театральных мистерий.

Более счастливую судьбу имели его пьесы «Вавилон», «Сын звезд» (ее постановку сопровождала музыка Э. Сати), «Византийский принц», «Семирамида», «Эдип и Сфинкс», «Орфей», «Аргонавты», «Тайна Грааля».

Свою театральную эстетику Пеладан в концентрированном виде изложил в труде «Происхождение и эстетика трагедии» (1905), уже по названию перекликающимся с «Рождением трагедии из духа музыки» (1871) Фридриха Ницше, посвященном кумиру Пеладана (и кумиру Ницше в период написания этой работы) Рихарду Вагнеру. Вагнеровские оперы были для него идеалом тотального, «абсолютного» театра, взыскующего сильных, почти невероятных чувств, возрождающего сакральные представления и легенды древности.

Предметом его интереса являются, прежде всего, эстетическая сущность трагедии и трагического. Водораздел между категориями трагического и прекрасного Пеладан усматривает в том, что драме чужд один из законов красоты - пропорциональность. Главным в трагедии он считает не красоту формы, не «искусство для искусства», но ее мистический план. Под этим углом зрения он анализирует природу античных трагедий, характер их метафизического «тайного учения».

Главным в театре античной Греции представляется Пеладану идеальное сочетание искусства, веры и инициации, художественности и мистицизма, стремление заглянуть в потустороннее, выйти за границы полной страданий жизни, найти духовный путь избавления от ее тягот. Примеры такого духовного становления личности он усматривает в дионисийстве как эзотерической и экзотерической тайной доктрине, ритуале вакхической секты с ее культом вина как символа наслаждения и свободы, культивирующей идеи духовного освобождения задолго до христианства. В Дионисе он видит единственного театрального протагониста, выступающего под различными масками - то Прометея, то Эдипа, то Ореста. Античные дифирамбы Пеладан интерпретирует как песнь инициации, возвестившей бессмертие человека, мистическое возвышение его души, открывшей горизонт становления; как пророчество древнегреческого театра о победе демона над богами, человека над роком - и это за много веков до возникновения христианства. Прометей для него - символ героизма и освобождения, Эдип - справедливости, искупления вины, спасения души, Антигона - сознательного самопожертвования. И все они в совокупности восходят к Дионису как благородному, возвышенному идеалу, хранителю тайного знания. Священное в античной Греции возвещало о себе в сценическом искусстве через танец, ритм; его символы - оракулы, эриннии, ладья Харона, змеи, чудовища, свет, сияние. В античном театре сочетались «все виды эстетического удовольствия, объединяющего ярость инстинкта и чистоту идеи» $[11$, с. 32], символизирующие «чудесное соседство смертного и бессмертного» [11, с. 69].

Пеладан убежден в том, что Эсхил и Софокл как посвященные в тайну человеческого предназначения мистики, метафизики, философы, а не только эстеты, основали и в то же время своим творчеством исчерпали трагедию. Они создавали свои шедевры в ту великую эпоху, когда кроме главной - сугубо эстетической - функции трагедия наделялась и другими: религиозной, социальной, патриотической; в те времена не шла речь об искусстве только как развлечении. Современный же ему французский театр подвергается Пеладаном бескомпромиссной критике как нацеленный исключительно на ублажение невзыскательной публики. В этом контексте его внимание привлекает проблема «Демократия и театр».

При анализе современного состояния театрального дела во Франции Пеладан исходит из того, что «художественная форма зависит от эпохи, а не от индивида, даже талантливого» $[11$, с. 88]. И если античная греческая демократия создавала идеальные условия для развития театра, то современные формы буржуазной демократии ему отнюдь не бла- 
гоприятствуют. В античном театре «вершины притягивают молнии, бурные страсти влекут за собой ужасные страдания, распахнутые крылья желания обрекают на удары судьбы» [11, с. 85], а греческий хор служит «патетической линзой». Греки, замечает Пеладан, умели соединить великое искусство и посредственную публику, «натянуть лук демократической трагедии» [11, с. 88], чего после них ни в одну из эпох развития европейской культуры никому сделать не удалось - ни Шекспиру, ни Расину, ни Гёте. Во времена же буржуазного индивидуализма мельчает всё, в том числе и театральное искусство. Если в античности трагедия была церемониалом, предопределяющим грандиозные условности, поражающую воображение декламация, то теперь их заменила обычная повседневная речь. Внимание перенесено с пьесы на игру актеров, что благоприятствует актерскому волюнтаризму.

Как драматург, театральный деятель и теоретик театра Пеладан приходит к неутешительному выводу о том, что в условиях буржуазной демократии трагедия, это чудное творение Диониса, умерла. Она пролетела, как метеор, но оставила в наследство потомкам тип «эстетической красоты» $[11$, c. 89], и поныне влекущий людей к театру.

В будущем, по мысли Пеладана, на театре могут вновь возникнуть грандиозные темы в сочетании со средней публикой - предтечей этому служат оперы Вагнера. В любом случае, заключает он, несмотря на современный упадок театра, он является высшим выражением индоевропейской расы, великим ритуалом европейской цивилизации.

В своем художественном вердикте Пеладан безапелляционен: «Я - царь, все - ничто» [11, с. 45], заявляет он в присущем ему эпатажном духе. Однако его шокировавший обывателей поведенческий демонизм оказывается, на наш взгляд, декларативным применительно к сфере эстетики и философии искусства. Три его ипостаси - символиста, неоклассика и эзотерика - образуют парадоксальное, но достаточно органическое единство. Его размышления о сущности эстетического, специфике разных видов и жанров искусства объединены пафосом отстаивания вечно прекрасного, абсолютного идеала, нетленных идей, духовной наполненности, художественности искусства, глубокой убежденностью в том, что «Искусство - Бог» [11, с. 64].

При этом нельзя не заметить определенной противоречивости в его метафизике искусства. Несмотря на постоянное выдвижение в теоретических суждениях на первое место почти классической эстетической теории, в которой приоритетным является именно художественное выражение, на практике, в своих конкретных анализах крупнейших произведений действительно высокого искусства он вольно или невольно отдает предпочтение рассудочно-аналитическому, нередко предельно субъективному толкованию реальной, а часто и надуманной символики этих произведений. В древней дохристианской мифологии усматривает прообразы христианско-католических идей и мифологем; в шедеврах европейского искусства ищет те эзотерические слои, о которых, возможно, даже и не подозревали их авторы, да, не исключено, что их там и вовсе нет. Между тем, именно эта эзотерическая метафизика искусства Сара Пеладана увлекала многих французских, да и не только, символистов. Некоторые из них видели в нем своего рода гуру от искусства. И нужно признать, что искушенность в мистико-эзотерической сфере, стремление проникнуть в тайный символический смысл классических шедевров придают эстетическим исканиям этого артистического мистика, а иногда и мистификатора искусства особый колорит, определяют оригинальность творческой личности Сара Пеладана как одного из значимых теоретиков и практиков французского символизма.

\section{Список литературы:}

1. Бычков В.В. Эстетика отрицания эстетического // Лев Николаевич Толстой. М.: РОССПЭН, 2014. С. $327-347$.

2. Книга о живописи мастера Леонардо до Винчи живописца и скульптора флорентийского. Перевод А.А. Губера, В.К. Шилейко под общей редакцией А.Г. Габричевского. М., ОГИЗ - ИЗОГИЗ, 1934.С.15-105.

3. Лосев А.Ф.Проблема символа и реалистическое искусство. М., Искусство, 1976. С.270-271.

4. Маньковская Н.Б. Эстетическое credo «демона» французского символизма Жозефена Пеладана // Вопросы философии, № 5, 2016. С. 80-92.

5. Толстой Л.Н. Что такое искусство? // Толстой Л.Н. Собр соч. в 20-ти тт. Т. 15. Статьи об искусстве и литературе. М., Художественная литература, 1964.С. 73-154.

6. Leonard de Vinci. Traité de la Peinture. Traduction nouvelle d'après le Codex Vaticanus avec un commentaire perpétuel par Péladan. 5 éd. P.: Librairie Ch. Delagrave, 1920. C.10-105.

7. Péladan J. Amphithéâtre des sciences mortes. III. Comment on devient Artiste. Esthétique. P.: Chamuel, 1894. C.5-80.

8. Péladan J. L'Art idéaliste et mystique. Doctrine de l'Ordre et du Salon annuel des Rose-Croix, 2º́d. P.: Chamuel, 1894. C. 52-53.

9. Peladan J. Théâtre de la Rose + Croix. La Prométhéide. P.: Chamuel, 1895.C. 151.

10. Péladan J. La Décadence Esthétique. Réponse à Tolstoï. P.: Chamuel, 1898.C. 7-271.

11. Peladan J. Origine et Esthétique de la Tragédie. P.: Sansot, 1905. C. 91.

12. Péladan. La Doctrine de Dante. P., Bibliothèque internationale d'édition, 1908.C. 39-110. 


\section{Филология: научные исследования 2(22) • 2016}

\section{References (transliterated):}

1. Bychkov V.V. Estetika otritsaniya esteticheskogo // Lev Nikolaevich Tolstoi. M.: ROSSPEN, 2014. S. 327-347.

2. Kniga o zhivopisi mastera Leonardo do Vinchi zhivopistsa i skul'ptora florentiiskogo. Perevod A.A. Gubera, V.K. Shileiko pod obshchei redaktsiei A.G. Gabrichevskogo. M., OGIZ - IZOGIZ, 1934.S.15-105.

3. Losev A.F.Problema simvola i realisticheskoe iskusstvo. M., Iskusstvo, 1976. S.270-271.

4. Man'kovskaya N.B. Esteticheskoe credo «demona» frantsuzskogo simvolizma Zhozefena Peladana // Voprosy filosofii, № 5, 2016. S. 80-92.

5. Tolstoi L.N. Chto takoe iskusstvo? // Tolstoi L.N. Sobr soch. v 20-ti tt. T. 15. Stat'i ob iskusstve i literature. M., Khudozhestvennaya literatura, 1964.S. 73-154.

6. Leonard de Vinci. Traité de la Peinture. Traduction nouvelle d'après le Codex Vaticanus avec un commentaire perpétuel par Péladan. 5 éd. P.: Librairie Ch. Delagrave, 1920. S.10-105.

7. Péladan J. Amphithéâtre des sciences mortes. III. Comment on devient Artiste. Esthétique. P.: Chamuel, 1894. S.5-80.

8. Péladan J. L'Art idéaliste et mystique. Doctrine de l'Ordre et du Salon annuel des Rose-Croix, $2^{\circ}$ éd. R.: Chamuel, 1894. S. 52-53.

9. Peladan J. Théâtre de la Rose + Croix. La Prométhéide. P.: Chamuel, 1895.S. 151.

10. Péladan J. La Décadence Esthétique. Réponse à Tolstoï. P.: Chamuel, 1898.S. 7-271.

11. Peladan J. Origine et Esthétique de la Tragédie. P.: Sansot, 1905. S. 91.

12. Péladan. La Doctrine de Dante. P., Bibliothèque internationale d'édition, 1908.S. 39-110. 